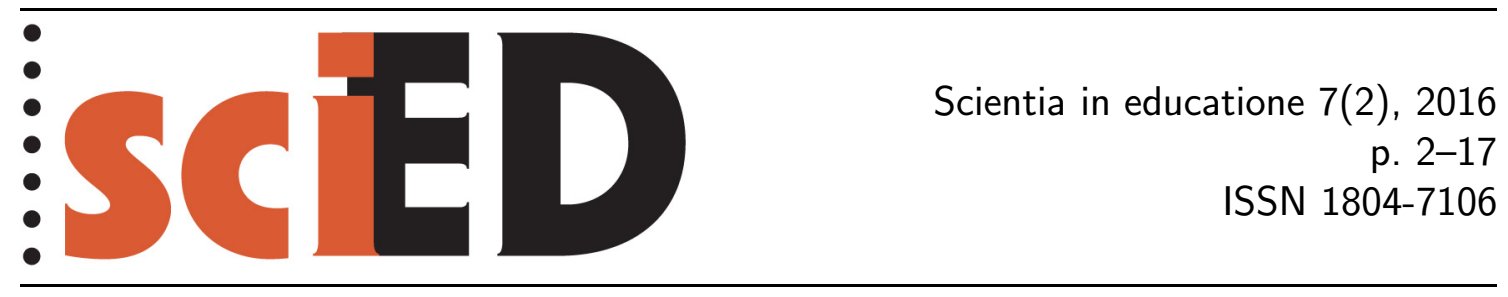

\title{
Rozvoj vědeckého myšlení žáků prostřednictvím přírodovědného vzdělávání
}

\author{
Eva Hejnová, Dalibor Hejna
}

\begin{abstract}
Abstrakt
Přehledová studie prezentuje strukturu dovedností, které pomáhají rozvíjet vědecké myšlení žáků. V první části studie jsou uvedena východiska, která ukazují, že obecný rozumový vývoj dítěte může být zlepšen určitým přístupem $\mathrm{k}$ výuce základů přírodních věd, jenž spočívá v důrazu na rozvoj metakognitivních kompetencí. V druhé části studie je prezentováno třináct dovedností (ve smyslu způsobilostí k vědecké práci), které podporují rozvoj vědeckého myšlení žáků. Ty jsou rozděleny na základní dovednosti (basic science process skills) a vyšší (integrované) dovednosti (integrated science process skills). Ke každé dovednosti jsou uvedeny příklady učebních činností, které jsou využitelné v běžné školní výuce. Předložená struktura dovedností a př́klady aktivit mohou být východiskem pro vytváření dalších činností, které budou žákům pomáhat v rozvoji jejich vědeckého myšlení.
\end{abstract}

Klíčová slova: přírodovědné vzdělávání, vědecké myšlení, metakognitivní kompetence, science process skills, učební činnosti.

\section{Development of Science Reasoning Abilities Through Science Education}

\begin{abstract}
The survey study presents a structure of the skills that help pupils develop science reasoning abilities. In the first part of the study, the starting points are given, showing that the overall intellectual development of a child can be improved by a specific approach towards the school instruction of natural sciences, one which emphasises the development of metacognitive competences. The second part of the study elaborates on thirteen science process skills designed to foster the development of pupils' science reasoning abilities. These skills are divided into basic science process skills and integrated science process skills. Some examples of teaching activities are presented in order to specify each of the skills; these activities are practically applicable in everyday teaching. The proposed structure of science process skills and the presented activities can be used as the starting point for the creation of other activities that will help pupils to develop their science reasoning abilities.
\end{abstract}

Key words: science education, science reasoning ability, metacognitive competences, science process skills, teaching activities. 


\section{ÚVOD}

Dnešní rychle se měnící svět představuje pro vzdělávací systémy v různých zemích po celém světě velkou výzvu, na kterou se snaží více či méně úspěšně reagovat. Význam vzdělávání stále narůstá, zároveň se však mění i cíle a obsah vzdělávání. Odborná i laická veřejnost v České republice i v zahraničí proto vede na různých úrovních diskusi o tom, jakým zpơsobem bychom měli inovovat vzdělávací cíle a vzdělávací obsah, což se týká všech stupňů škol.

Ve všech přírodovědných oborech dochází k obrovskému nárůstu poznatků, které není možné jednoduchým způsobem převádět do vzdělávacích předmětů. Není totiž již důležité pouze to, co se dozvídáme, ale také to, jak se dokážeme v množství informací orientovat, jak umíme najít podstatné informace a jak je dokážeme zpracovat a použít. Klíčovou otázkou pro plánování vzdělávacího procesu je proto nejen jakou oblast $\mathrm{z}$ daného vědního oboru vybrat, ale i v jaké podobě a jakým způsobem ji do školní výuky v rámci př́rodovědných předmětů aplikovat.

Lze předpokládat, že na pracovním trhu budou úspěšní zejména ti uchazeči, kteří budou mít nejen příslušné znalosti a dovednosti, ale budou také samostatní, iniciativní a tvořiví, budou umět kriticky myslet, řešit problémy, samostatně se rozhodovat a v neposlední řadě budou umět své názory prosadit a realizovat (Koenig, 2011). Jedním z hlavních cílů dnešní školy je proto vést děti k samostatnému rozhodování a kreativitě.

$\mathrm{S}$ ohledem na velmi rychlý pokrok v oblasti přírodních věd a velké množství nových informací se ve vzdělávání přenáší důraz od získávání poznatků na osvojování obecných principů myšlení, tzv. metakognitivních ${ }^{1}$ kompetencí (Stuchlíková \& Mareš, 2014). Proto také nové vzdělávací cíle kladou důraz na klíčové kompetence, v nichž se metakognitivní procesy nejvíce projevují (viz např. kompetence k učení a kompetence $\mathrm{k}$ řešení problémů). Ty sice nemohou nijak nahradit specifické znalosti a dovednosti, nicméně bezpochyby přispívají nejen $\mathrm{k}$ lepší uplatnitelnosti na trhu práce, ale též k celkové kultivaci osobnosti (Straková, 2010). Promýšlení modernizace vzdělávacích cílů se v tomto kontextu proto jeví jako nezbytné a potřebné.

Cílem této přehledové studie je ukázat, jakými způsoby je možné rozvíjet obecné principy myšlení prostřednictvím výuky přírodovědných předmětů. V našem článku se konkrétně zaměřujeme na dovednosti, které pomáhají rozvíjet vědecké myšlení žáků, a na ilustrativních př́kladech chceme ukázat, jaké aktivity mohou k jeho rozvoji přispět. Vycházíme při tom ze struktury dovedností, kterou formulovala Americká společnost pro rozvoj vědy (American Association for the Advancement of Science, dále jen $\mathrm{AAAS}^{2}$ ), nebot tato klasifikace dovedností bývá v zahraniční literatuře v různých modifikacích používána nejčastěji (napřr. Padilla, 1990; Jinks, 1997). I když má naše studie převážně rešeršní charakter, domníváme se, že zpřístupnění těchto poznatků v ucelené podobě, jejich zasazení do širšího kontextu a uvedení konkrétních př́kladi̊ aktivit může být pro učitelskou veřejnost přínosné a inspirativní.

\footnotetext{
${ }^{1}$ Nejjednodušeji lze metakognici definovat jako „myšlení o našem myšlení, znalost o tom, co víme a co nevíme“ (Krykorková \& Chvál, 2001: s. 185). Podle Pedagogického slovníku (Průcha, Walterová \& Mareš, 2009: s. 152) je metakognice „schopnost jedince přemýšlet o tom, jak sám uvažuje, jak poznává svět“ nebo také „jedincova vědomá kontrola a řízení vlastních poznávacích procesů".

${ }^{2}$ American Association for the Advancement of Science. (1989). Project 2061: Science for all Americans. Washington: AAAS.
} 


\section{VÝCHODISKA}

Učitelé v českých školách často nekladou dostatečný důraz na takové cíle, jakými jsou rozvoj obecných myšlenkových dovedností, rozvoj experimentálních dovedností, osvojování metod vědeckého zkoumání, učení se týmové práci a podpora pozitivního postoje k přírodním vědám (Straková, 2010). Tuto skutečnost potvrzují i výsledky v prřírodovědných šetřeních TIMSS a PISA, ve kterých bylo zjištěno (Dvořák et al., 2008), že silnou stránkou českých žáků je zejména znalost přírodovědných poznatků, ale problémy jim dělá vytváření hypotéz, využívání různých výzkumných metod, experimentování, získávání a interpretace dat, posuzování výsledků výzkumu a formulování závěrů.

V rámci videostudie realizované v roce 1999 jako součást výzkumu TIMSS (Straková, 2010: s. 85) bylo např. zjištěno, že „alespoň jednu praktickou aktivitu obsahovalo pouze $23 \%$ českých hodin, pouze v $6 \%$ hodin však měli žáci za úkol něco objevovat, jinak plnili postup nebo potvrzovali poznatek". Malé zastoupení experimentální práce bylo shledáno rovněž ve výzkumu TIMSS 2007 a PISA 2006. Navzdory těmto zjištěným skutečnostem však zároveň mezinárodní šetření ukazují, že naši žáci dosahují v oblasti přírodovědné gramotnosti trvale nadprůměrných výsledků, což potvrdilo i poslední šetření PISA 2012 (ČŠI, 2013). Aktuální výsledky ze šetření PISA 2015, které bylo zaměřeno zejména na přírodovědnou gramotnost, budou zveřejněny koncem roku 2016, takže v současné době nelze říci, zda bude tento trend i nadále zachován. Straková (2010) ve své studii poukazuje ještě na jednu zajímavou skutečnost, která je specifická pro české školy. Tou je, že těžiště výuky je posunuto spíše k nižším úrovním taxonomie vzdělávacích cílů tj. důraz je kladen zejména na znalosti a na zvládání rutinních operací, naproti tomu rozvíjení obecných myšlenkových operací ustupuje spíše do pozadí.

Pokud hledáme cesty, jak tento stav změnit, je nutné a potřebné se zaměřit na aktivity, které žáci preferují, tj. zejména na praktické a badatelsky orientované aktivity a na výuku týkající se věcí a jevů spojených s reálným, každodenním životem (Kekule \& Žák, 2010). Badatelsky orientované výuce (Inquiry-Based Science Education, dále jen IBSE) je od 90 . let 20. století ve světě a v posledních letech i v českém vzdělávacím prostředí věnována velká pozornost (Papáček, 2010a; Minárechová, 2014). Navíc se tato cesta ukazuje jako vhodný způsob pro rozvoj klíčových kompetencí i v rámci nižšího primárního vzdělávání (Papáček, 2010b; Janoušková, 2014). Metoda IBSE umožňuje vytvářet a rozvíjet schopnosti a dovednosti žáků hledat a objevovat, zkoumat, porozumět vědeckých pojmům, objevovat vědecké principy atd.

Nicméně i tato metoda má mnohá omezení spočívající např. v nedostatečných znalostech a dovednostech žáků potřebných pro zkoumání. Tzv. otevřené bádání, při němž žáci a studenti sami sestavují výzkumné otázky, způsob a postup bádání, zaznamenávají a analyzují data a vyvozují závěry z informací, které shromáždili, vyžaduje již vysokou úroveň vědeckého myšlení a klade na žáky vysoké kognitivní požadavky, a je proto použitelné spíše pro starší nebo nadané žáky.

Na tuto skutečnost poukazuje např. Ogborn (2012), který namítá, že v rámci jedné vyučovací hodiny není možné opakovat celý proces skutečného vědeckého bádání, tj. ve smyslu objevování něčeho nového, nebot̉ skutečné objevování vyžaduje zpravidla velmi dlouhý čas. Celý proces reálného objevování je obvykle cestou omylů a hledání nových cest, které vyžaduje neustálé kritické posuzování dílčích závěrů. Dále Ogborn upozorňuje, že učitelé často kladou důraz na různé praktické aktivity, které žáci v rámci IBSE provádějí, ale opomíjejí nezbytnou kritickou reflexi toho, co studenti dělají, a především to, jak při tom přemýšlejí. 
Kromě výše uvedeného mnozí odborníci uvádějí, že „experimenty ve výuce nepodporují samy o sobě ani porozumění přírodovědným obsahům, ani způsoby myšlení a práce, ani zájem žáků “ (Dvořák, Kekule \& Žák, 2012: s. 329). Jedním z důležitých faktorů pro skutečné porozumění je využívání představ (prekoncepcí), které žáci o daném jevu mají, na základě nichž se pak může odvíjet diskuse a následné experimentování (Berg, 2013). Berg také poukazuje na to, že vyučování laboratorním technikám a badatelským dovednostem by mělo být dobře strukturované, jestliže má být účinné a vést ke skutečnému porozumění př́rodovědným pojmům.

\section{VĚDECKÁ METODA A ROZVOJ VĚDECKÉHO MYŠLENÍ}

Učení se přrírodním vědám má hierarchickou strukturu, která se opírá o pojmy a principy. Principy lze podle Gagného (1975: s. 138) chápat jako „řetězce pojmů, jež vytvářejí to, co bývá obecně nazýváno věděním“. Stručně lze říci, že principy vytvářejí vztahovost mezi pojmy. Jednotlivým principům se však neučíme izolovaně. Na základě úspěšného řešení praktického nebo teoretického problému můžeme získat „vhled“ do řešení a vytvořit si tak nový princip (ve smyslu „privátní“), který je vyššího řádu. Pokud si takto osvojíme vyšší princip, rozšiřujeme své způsobilosti (dovednosti) řešit složitější problémy.

Při osvojování vědeckého myšlení lze analogicky vycházet z určitého souboru dovedností, jež vytvářejí jistou hierarchii a jsou mezi sebou vzájemně propojeny bud' v logickém, nebo psychologickém smyslu, tj. osvojení nižší dovednosti je předpokladem k osvojení vyšší dovednosti (ale nutně tomu tak být vždy nemusí). Skutečnost, že došlo k osvojení těchto dovedností, je možné prokázat jen při řešení nějakého problému, úlohy, praktické činnosti apod. Takto osvojené dovednosti jsou pak odolnější vůči zapomínání a také pomáhají rozvíjet metakognitivní kompetence (Gagné, 1975). Některé dovednosti v prrírodních vědách lze přitom považovat za základní a je možné je zobecnit v tom smyslu, že jsou použitelné ve všech vědních disciplínách.

V českých učebnicích přírodních věd zpravidla není věnována potřebná pozornost dovednostem rozvíjejícím vědecké myšlení, nebot autoři často předpokládají, že si žáci tyto dovednosti osvojili již dříve nebo si je osvojí sami během školního vzdělávání. Často tomu tak ale nebývá a osvojování těchto dovedností by měla být věnována dostatečná pozornost $\mathrm{v}$ úvodních hodinách přírodních věd $\mathrm{i} \mathrm{v}$ průběhu dalšího přírodovědného vzdělávání na všech stupních škol.

Učení se obecným principům myšlení je základem tzv. vědecké metody. Metodu vědeckého poznávání (nazývanou také stručně vědecká metoda) obvykle chápeme jako soubor nebo posloupnost pravidel, kterými se řídíme v procesu získávání vědeckých poznatků o určité oblasti. Vědecká metoda zahrnuje jednak soustavu utř́děných myšlenkových operací, a jednak soustavu činností a technik (ve smyslu vnějších činností) zaměřených k určitému cíli (Fenclová, 1984a). Předpokladem vědecké metody a vědeckého myšlení je dodržování určitých standardů (Koukolík, 2013), jimiž jsou jasnost, přesnost, určitost, věcnost, hloubka, ššřka a logika. Vědecké myšlení je pak možné považovat za určitou (vyhraněnou) podobu kritického myšlení ${ }^{3}$.

Je nutné podotknout, že neexistuje jedna jediná vědecká metoda, vhodnější je mluvit spíše o vědeckých metodách. Každá vědecká metoda je však založena na předpokladu, že kritériem pravdivosti vědecké hypotézy je souhlas předpovědi s výsledky

\footnotetext{
${ }^{3}$ Koukolík (2013: s. 12) charakterizuje kritické myšlení jako „pečlivé a uvážené rozhodnutí o tom, zda nějaké tvrzení přijmeme, odmítneme, nebo se o něm zřekneme úsudku“. Kritické myšlení také zahrnuje stupeň jistoty, s níž nějaké tvrzení přijmeme nebo odmítneme.
} 
výzkumu. Žádné tvrzení nemůže být akceptováno jako apriorní a každý vědecký poznatek může být vyvrácen, má pouze podmíněnou platnost (vědecká metoda zahrnuje vždy možnost falzifikace hypotéz). Soubor mnohokrát ověřených a potvrzených hypotéz se v rámci určitého paradigmatu stává vědeckou teorií, přičemž každá z hypotéz, na níž je založena vědecká teorie, musí být vyvratitelná (o tvorbě hypotéz je podrobněji pojednáno v podkapitole 3.2.2). Dobrá teorie musí být v souladu se všemi známými fakty a musí vysvětlovat pozorování co možná nejjednodušším způsobem. Teorie pak může přestat být platná v rámci nového paradigmatu.

Filozofie vědy dělí vědecké metody na empirické a logické podle vztahu ke smyslové a racionální složce poznání ${ }^{4}$ (Fajkus, 2005). K empirickým metodám patří pozorování, srovnávání, analýza a experiment (Richterek, 2008). Mezi logické metody řadíme indukci, dedukci, syntézu, abstrakci, generalizaci a analogii. Vědecké poznatky, které získáme empirickými a logickými metodami, je třeba zařadit do určitého systému. $\mathrm{K}$ tomuto účelu věda používá klasifikace, hypotézy, teorie a zákony.

V oblasti vzdělávání se v současné době uplatňuje zejména tzv. induktivní způsob vyučování, který stojí v základu různých konstruktivisticky orientovaných metod (např. IBSE), které stavějí na aktivitách žáka, jež by měly kopírovat práci vědce (Minárechová, 2014). Pro vzdělávání je ale zejména podstatné to, aby se žáci dozvěděli, co odlišuje vědecké myšlení od běžného přemýšlení a uvažování.

Mluvíme-li o rozvoji vědeckého myšlení ve vzdělávacím procesu, pak máme zpravidla na mysli rozvoj takového stylu myšlení, $\mathrm{k}$ němuž např. patř́i schopnost formulovat a ověřovat hypotézy, předvídat budoucí jevy na základě znalostí, dovednost zobecňovat, klást si a rozpoznat otázky, které je možno zodpovědět pomocí vědeckého zkoumání, vyvozovat závěry ze získaných poznatků a kriticky hodnotit cizí závěry, plánovat, komunikovat získané poznatky atd.

\section{UČEBNÍ ČINNOSTI PODPORUJÍCÍ ROZVOJ VĚDECKÉHO MYŠLENÍ ŽÁKŮ}

\subsection{Struktura DOVEDNOSTí ROZVÍJEJíCíCH METAKOGNITIVNí KOMPETENCE ŽÁKŮ}

V této kapitole se budeme zabývat strukturou učebních činností, které pomáhají při rozvíjení dovedností zaměřených na rozvoj vědeckého myšlení a přispívají k rozvoji metakognitivních kompetencí. Dovednost zde podle Trny (1998: s. 10) budeme chápat jako „získanou kompletní způsobilost k řešení úkolových a problémových situací v podobě kognitivní struktury, která se projevuje pozorovatelnou činností“.

Současné výzkumy naznačují (viz např. projekt CASE - Cognitive Acceleration through Science Education, Adey, 1999), že žáci si mohou osvojovat základní postupy vědecké práce prostřednictvím specifických činností zaměřených na rozvíjení dovedností myšlení a učení. Tyto činnosti předpokládají osvojení určitých dovedností, které jsou v zahraniční literatuře označovány science process skills, což lze překládat jako způsobilosti vědecké práce (Minárechová, 2014). Padilla (1990) je definuje jako soubor široce přenositelných dovedností, které jsou využitelné v mnoha vědních disciplínách a které reflektují to, jak vědci pracují.

AAAS formulovala třináct těchto dovedností, které rozdělila na základní (basic science process skills) a vyšší (integrované) dovednosti (integrated science process skills).

\footnotetext{
${ }^{4}$ Jedná se pouze o základní dělení.
} 
1. pozorování (observation);

2. měření (measurement);

3. třídění (classification);

4. kvantifikace (quantification);

5. usuzování (inferring);

6. předpovídání (predicting);

7. hledání vztahů (identifiing variables, relationships);

8. komunikace (communication).

Mezi vyšší dovednosti patří:

9. interpretace (výklad) (interpreting data);

10. kontrola proměnných (controlling variables);

11. definování (operational definitions);

12. tvorba hypotéz (hypothesizing);

13. experimentování (experimenting).

Oporu pro třridění na základní a vyšší dovednosti lze nalézt u Piageta, který rozlišuje dva aspekty poznání - figurativní a operační (Piaget, 1970; Kratochvíl, 2006: s. 52). Figurativní aspekt poznání odkazuje ke smyslům a je předpokladem pro vytváření tzv. empirické abstrakce, kterou provádíme na základě odvozování společných vlastností z dané třídy objektů. Tato abstrakce je základem induktivního poznání. Operační aspekt odkazuje na činnost a je předpokladem pro tzv. reflexivní abstrakci, která je základem logicko-matematického poznání. Z hlediska inteligence pak Piaget rozlišuje mezi senzomotorickou a pojmovou inteligencí (Piaget, 1999).

Na základě Piagetovy teorie inteligence formulovala Krykorková (2008) teorii dvou kognitivních úrovní. Kognitivní úroveň I odpovídá figurativnímu aspektu poznání a zahrnuje kognitivní činnosti nižší úrovně, které lze označit jako učení s porozuměním. Žák si může pomocí těchto činností osvojit základní metakognitivní dovednosti. Kognitivní úroveň II zahrnuje činnosti vyšší úrovně, odpovídá operačnímu aspektu poznání a umožňuje rozvíjet metakognitivní dovednosti vyšší (obecnější) úrovně. Krykorková také uvádí, že hranice mezi těmito dvěma úrovněmi není ostrá, může mezi nimi být jistý přesah, tj. činnosti vyšší úrovně mohou být „elementarizovány" a v jednodušší podobě je lze rozvíjet i na úrovni I. Činnosti na úrovni I může zvládnout většina žáků 1 . stupně základní školy, úroveň II se pak týká spíše starších žáků na 2. stupni základní školy a středoškoláků.

Krykorková (2008) dále uvádí výčet činností, které rozvíjejí metakognitivní dovednosti na úrovni I a II. Vychází při tom z myšlenky, že poznávací aparát je mnohaúrovňový a hierarchicky uspořádaný systém a navrhuje modifikaci Bloomovy taxonomie kognitivních cílů tak, aby vyhovovala lépe možnosti aplikace metakognitivní teorie do školní praxe. Kognitivní úrovni I přiřazuje v souladu s Bloomovou taxonomií znalost, porozumění (interpretaci) a aplikaci. Do kognitivní úrovně II zařazuje nově tvořivost a řešení problému. Jimi nahrazuje $\mathrm{v}$ tradiční Bloomově taxonomii analýzu a syntézu. Do kognitivní úrovně II zahrnuje kromě tvořivosti a řešení problému ještě hodnocení (resp. hodnotící posouzení), které je v tradiční Bloomově taxonomii zahrnuto. 


\subsection{ChARAKTERISTIKA A PŘÍKLADY UČEBNíCH ČINNOSTÍ ROZVÍJEJÍCÍCH VĚDECKÉ MYŠLENÍ ŽÁKŮ}

V této části příspěvku uvedeme přehled základních a vyšších dovedností, přičemž budeme vycházet z dělení navrženého AAAS. U každé dovednosti uvedeme její stručnou charakteristiku a návrh aktivit, které podporují osvojení dovednosti, včetně doporučení pro vzdělávací praxi.

\subsubsection{ZÁkladní dovednosti (Basic Science Process Skills)}

\section{1) Pozorování}

Pozorování je základem pro rozvoj všech dalších dovedností, nebot bývá východiskem pro další analýzu, klasifikaci apod. Každé pozorování obvykle zahrnuje záznam výsledků pozorování, přičemž je důležité, aby žáci nezaznamenávali své subjektivní dojmy nebo názory, ale pouze objektivní výsledky svého pozorování. Žáci by se také měli naučit rozlišovat, že je rozdíl mezi tím, co pozorují, a tím, jak svá pozorování interpretují. Např. je rozdíl mezi tvrzením „Ty divky jsou si velmi podobné“ (jde o pozorování) a "Ty dívky jsou si velmi podobné, jsou to dvojčata" (v tomto př́́padě se již nejedná o výsledek pozorování, ale interpretaci toho, co pozorujeme, která navíc nemusí být pravdivá).

Při pozorování by měli žáci zapojit co nejvíce svých smyslů a $\mathrm{k}$ popisu toho, co pozorují, využít různé formy záznamu (slovní vyjádření, obrázky, grafy atd.). K pozorování je možné též užít různých přístrojů (napřr. mikroskop, dalekohled atd.).

Pro rozvoj metakognitivních dovedností je důležité, aby žáci porovnávali své záznamy s ostatními žáky a zjištovali, v čem jsou jejich pozorování originální (tj. čeho si ostatní nevšimli) a co se naopak mohou naučit od ostatních (čeho si všiml někdo jiný).

\section{PříKLADY AKTIVIT}

- Pozoruj pohyb lidí na ulici, tvary a umístění předmětů ve tř́idě. Napiš nebo nakresli, jak předměty vypadají, co lidé dělají apod. (Žáci mohou např. sledovat různé tvary, rychlost, směr pohybu, shodné nebo rozdílné znaky atd.)

- Vlož sáček čaje do vyšší sklenice, opatrně ho zalij teplou vodou a pozoruj, co se děje (žáci mohou kreslit a písemně zaznamenávat, co pozorují v různých okamžicích, všímat si barev, vůně, chuti apod.).

- Pozoruj hořící svíčku (žáci mohou zakreslit např. plamen svíčky, popsat jeho barvy, zaznamenat, jak daleko od plamene cítí teplo, co cítí atd.) (příklad aktivity podle Fenclové, 1984b).

- Pozoruj pingpongový míček, který padá na stůl (žáci mohou pozorovat, jak se mění výška po odrazu míčku od stolu, sluchem mohou postihnout, jak se mění interval mezi jednotlivými dopady míčku apod.).

\section{2) MĚřENÍ}

Měření lze považovat za specifický druh pozorování, při kterém porovnáváme měřitelnou vlastnost objektu nebo systému s nějakým standardem. Dovednost „měřit“ zahrnuje i dovednost odhadování velikostí různých charakteristik objektů nebo systémů. Žáci by si měli uvědomit, že údaje, kterými kvantifikujeme různé systémy, mohou více či méně záviset na subjektivním hledisku (napřr. měříme-li vzdálenost 
a zvolíme-li jako jednotku délky loket osoby, která měření provádí, nebo hodnotíme-li známkami výkony žáků, které se objektivně obtížně hodnotí, např. přednes básně).

\section{PřÍKLADY AKTIVIT}

- Změř délku stolu pomocí vlastní jednotky. Odhadni délku stolu v centimetrech a proved' měření pomocí vhodného měřidla. Porovnej svůj odhad s výsledkem tvého měření (př́klad aktivity podle Hejnové, 2009).

- Odhadni, kde asi bude hladina vody, jestliže ji postupně přeliješ do nádob různých tvarů (př́klad aktivity podle Hejnové, 2011).

\section{3) TříDĚNí}

Třídění představuje proces seskupování objektů nebo jevi̊ na základě vybraných pozorovatelných znaků (vlastností). Objekty, které sdílejí stejné znaky, pak zařazujeme do stejné skupiny (množiny). Proces třídění je přitom závislý na volbě kritéria, podle kterého třídíme, což vnáší do celého procesu určitou míru subjektivity. Třídit lze podle jednoduchých vnějších znaků (např. podle barvy, tvaru apod.). Tyto charakteristiky však nemusí nutně vystihovat skutečnou podstatu (esenci) systému (např. chceme-li roztřídit živočichy na kočky a „ne-kočky“, musíme si položit otázku, co dělá kočku kočkou neboli co je podstata „kočkovitosti“). Povaha „dovednosti tř́ídit" zahrnuje tedy dva aspekty: nalezení tř́dících znaků a výběr těch, které postihují hlubší podstatu tříděného systému objektů nebo jevů.

Při osvojování dovednosti třídění žáci zpočátku hledají jednoduché třídící znaky, přičemž je důležité, aby hledali různá kritéria pro třídění a zároveň dokázali třídit skupinu objektů nebo jevů podle více kritérií zároveň (vícenásobné třídění).

\section{PŘÍKLAD AKTIVITY}

- Vymysli, podle jakých kritérií by se daly předměty, které vidíš před sebou, roztřídit (žáci mohou mít $\mathrm{k}$ dispozici např. tyto předměty: dřevěnou kostku, kousek uhlí, skleněnou kuličku, vodu, benzin, měděný drátek, ocelový šroubek, gumu, kousek celofánu, líh; je vhodné, aby žáci mohli s předměty manipulovat). Porovnej vytvořené skupiny mezi sebou. Co mají společného a v čem se liší? Vymyslel jsi nějaké třídící kritérium, které nemají ostatní? Navrhni vhodné třídění podle dvou kritérií zároveň.

\section{4) KVAntifikace}

Kvantifikace zahrnuje proces shromažd’ování údajů o pozorovatelných jevech a jejich vyjádření ve formě čísel. Přednost procesu kvantifikace spočívá v tom, že umožňuje jednodušeji a stručněji vyjádřit to, co bychom museli složitě popisovat slovně, a zároveň umožňuje použivat pravidla matematické logiky. Kvantifikace tak umožňuje snížit míru subjektivity - číselný údaj je objektivnější vyjádření určité vlastnosti objektu než její slovní popis (např. „Voda v hrnku je vlažná.“ vs. „Voda v hrnku má v tomto okamžiku teplotu $29^{\circ} \mathrm{C}$. “), dále umožňuje řazení podle číselných hodnot (např. od největší hodnoty k nejmenší), vyhledávání prostřední hodnoty (mediánu) a nejčastěji se vyskytující hodnoty (modu). 


\section{PřÍKLADY AKTIVIT}

- Zjisti, kolik žáků z vaší třídy má nějaké zviřre (psa, kočku, ...). Svoje zjištění zapiš do tabulky. Najdi největší a nejmenší hodnotu a nejčastěji se vyskytující hodnotu.

- Spočítej, kolik fazolí se vejde do skleničky apod. Měření zopakuj vícekrát. Výsledky měření zapiš do tabulky. Najdi nejmenší a největší hodnotu a vypočítej průměr. Porovnej údaje z jednotlivých měření.

- Zjisti, kolik žáků ve třídě jsou bruneti a kolik je blondýnů. V tomto př́padě musí žáci nějakým způsobem vhodně kvantifikovat, který žák bude patřit mezi blondýny a který mezi brunety. To mohou učinit např. tak, že určí škálu „blond’atosti", a definují nejmenší a nejvyšší míru této vlastnosti pomocí číselného vyjádření (např. Lenka má nejsvětlejší blond’até vlasy ve tř̌́dě, tudíž jí přisoudíme míru „blond’atosti“ rovnu jedné, Marek má nejtmavší vlasy, které ještě označíme jako blond’até, přisoudíme mu míru „blond’atosti“ rovnu pěti. Všem ostatním žákům bude přisouzena míra „blond’atosti“ na této stupnici v rozmezí jedna až pět (přičemž je možné připustit i použití jemnějšího dělení) (příklad aktivity podle Jinkse, 1997).

\section{5) Usuzování}

Usuzování je myšlenkový proces, při kterém hledáme přičinu, pomocí níž bychom dokázali vysvětlit určitý pozorovaný jev. Usuzování závisí na nápaditosti a důvtipu usuzující osoby a jeho výsledek je ve značné míře ovlivněn osobností usuzujícího i dalšími, např. kulturními, aspekty (např. „Dostal jsem pětku, protože jsem se neučil.“ vs. „Dostal jsem pětku, protože si na mě učitel zasedl.“).

\section{Př́́KLADY AKTIVIT}

- Promysli, na čem může záviset výsledek tvého počítání fazolí v předchozí úloze. Vymysli co nejvíce přičin, které mohly výsledek tvého počítání ovlivnit.

- Proč se střídá den a noc? Vymysli různá vysvětlení, která mohou lidé mít (např. malé děti, pravěcí lidé atd.).

- Prohlédni si pozorně fotografie povrchu Marsu a Venuše. Proč si myslíme, že na předměty na Marsu a na Venuši působí gravitační síla? (př́íklad aktivity podle Hejnové, 2011).

\section{6) PŘEdPovídÁní}

Při předpovídání vycházíme z dat a znalostí (případně i ze zkušeností a intuice), které máme v okamžiku předpovědi $\mathrm{k}$ dispozici. Pomocí nich pak usuzujeme, co se stane v budoucnu, tj. můžeme usuzovat na určitý trend nebo dění. Každá předpověd' (na rozdíl od pouhého hádání) musí být vždy ověřitelná (testovatelná), tj. můžeme ji přijmout či zamítnout na základě nějakého pozorování nebo na základě určitých kritérií (např. předpověd” „Pokud hodíme miček z okna, spadne na zem. "lze testovat, kdežto předpověd' „Pokud se drak probudí, země se otřese." testovat zřejmě nejde).

\section{PřÍKLAD AKTIVITY}

- V nákladové části kamionu stojí na podlaze kbelík s vodou, na zemi je položen tenisový míček, u stropu je zavěšeno lano a na zemi leží prázdná papírová kra- 
bice. Kamion jede po přímém a rovném úseku silnice. Krabice se náhle převrátí (ve směru jízdy). Předpověz, co se v tomto okamžiku bude dít s tenisovým míčkem, lanem a jaká bude poloha hladiny vody v kbelíku (př́klad aktivity podle Hejnové, 2004).

\section{7) HLEdÁNí VZTAHŮ}

Jedná se o objevování vztahů a souvislostí mezi dvěma nebo více proměnnými. Základem této dovednosti je využívání analytického přístupu, pomocí něhož zkoumáme chování nějakého systému. Hledáme-li vztahy mezi veličinami, určujeme, které veličiny se mění v závislosti na jiných (tj. určujeme závisle a nezávisle proměnné veličiny).

\section{PŘÍKLADY AKTIVIT}

- Před školou má být umístěna dopravní značka, která by řidiče upozorňovala na zvýšený pohyb dětí. Které proměnné je třeba sledovat, aby bylo možné správně rozhodnout, do jaké vzdálenosti před školou je vhodné značku umístit? (př́klad aktivity podle Hejnové, 2004).

- Ondřej zjištuje pevnost čtyř různých vláken. Které veličiny musí měřit? Která veličina bude nezávisle proměnná? (příklad aktivity podle Hejnové, 2004).

\section{8) Komunikace}

Jedná se o dovednosti, které jsou zaměřeny na sdělování zjištěných informací v ucelené a přehledné podobě (např. ve formě tabulek, schémat, diagramů nebo grafư). Pro uspořádávání informací je klíčovou dovedností nalézt a prezentovat vhodným (systematickým) způsobem vztahy mezi proměnnými veličinami.

\section{PříKLAD AKTIVITY}

- Popiš, jak se mění výška rostliny (např. fazole) v závislosti na čase (sestav vhodnou tabulku, sestroj graf) (př́íklad aktivity podle Rojka, 1995).

\subsection{VyŠŠí (integrované) DOVednosti (Integrated ScIEnce PROCESS SKILlS)}

\section{9) INTERPRETACE (VÝKLAD)}

Tato dovednost úzce souvisí s předchozí dovedností uspořádávat a sdělovat získané informace. $\mathrm{V}$ tomto případě se ale jedná o schopnost nalézání vnitřní povahy jednotlivých informací a vztahů mezi nimi a jejich vysvětlování. V návaznosti na to pak následuje vyvozování závěrů. Interpretace již vyžaduje vyšší míru tvůrčího myšlení, nebot také zahrnuje dovednost nalézání obecnějších ( „zastřešujících“) pojmů.

\section{Př́́KLAD AKTIVITY}

- Dopravní policisté sledují pomocí kamery automobilový provoz na úzké silnici. $\mathrm{Na}$ silnici byly po určité době vyznačeny bílé vodící čáry. Na jednom úseku úzké silnice pak bylo zjištěno, že poté, co byly vodící čáry vyznačeny, se provoz změnil tak, jak je uvedeno v tab. 1. 
Tab. 1: Změny

v provozu po vyznačení vodících čar
Rychlost aut Provoz je rychlejší.

Umístění vodících čar Provoz je blíže k okrajům silnice. Vzdálenost mezi auty Je beze změn.

Na základě těchto výsledků bylo rozhodnuto, aby vodící čáry byly vyznačeny na všech úzkých silnicích. Myslíš, že to bylo nejlepší rozhodnutí? Uved’ důvody svého souhlasu nebo nesouhlasu (př́klad aktivity podle PISA, 1999).

\section{0) KONTROLA PROMĚNNÝCH}

Jedná se o dovednost, která umožňuje za pomoci analytického myšlení nalézt u zkoumaného systému určitou proměnnou veličinu, která ovlivňuje jeho chování. S pomocí různých postupů (např. opakování měření, standardizace procedur zahrnující přesné určení experimentálních podmínek apod.) identifikujeme veličiny, které je třeba při provádění experimentu udržovat konstantní, abychom mohli zkoumat vztah mezi vybranými dvěma veličinami.

\section{PŘÍKLADY AKTIVIT}

- Radek měří rychlost proudění vody v potoce. Je březen a potokem protéká velké množství vody. Radek se rozhodnul, že své měření zopakuje v srpnu. Uved' alespoň jednu podmínku, kterou musí při svém měření dodržet, aby jeho výsledky byly spolehlivé (příklad aktivity podle Hejnové, 2004).

- Katka chce zjistit, jaký vliv na rychlost růstu fazole má určitý druh hnojiva. Které proměnné veličiny musí kontrolovat, aby její měření bylo spolehlivé (příklad aktivity podle Padilly, 1990).

\section{1) Definování}

Jedná se o dovednost formulovat tzv. operacionální definice, kterými popisujeme postupy nebo činnosti, jejichž provedením získáme definovaný pojem (př́klady operacionálních definic: „Inteligence je to, co je měreno inteligenčními testy. ", „Okamžitá rychlost je to, co měř́me tachometrem. "), nebo na jejichž základě je tento pojem identifikován (např. postup, jak vyrobit oxid uhličitý). Operacionální definování musí naplňovat požadavek opakovatelnosti a ověřitelnosti. Definovaný pojem musí být vyjádřen explicitně, přičemž význam definovaného pojmu musí být jasný tak, aby jeho definice nevyžadovala žádnou další interpretaci či doplnění.

\section{PřÍKLADY AKTIVIT}

- Definuj hmotnost tělesa pomocí měření na pružině.

- Popiš postup, jak najdeš ohnisko spojné čočky.

\section{2) TVORBA HYPOTÉz}

Vědecká hypotéza je možné řešení nějakého problému, které vyslovujeme ve formě tvrzení. Formulace hypotézy vychází v přírodních i humanitních vědách vždy z určitého vědeckého paradigmatu (Kuhn, 1997). Paradigma zahrnuje jednak samu nauku, tj. myšlenkové komplexy, cíle bádání, postupy a symbolická vyjádření, která jsou 
vlastní určité vědecké činnosti, a jednak organizaci vědy, tj. způsob její výuky, odborný jazyk, předkládání poznatků, metodické postupy, laboratorní vybavení, formulace problémů a zpo̊soby jejich řešení. Na tomto pozadí jsou pak vytvářeny teorie, v rámci nichž lze teprve vyslovovat testovatelné, tj. experimentálně ověřitelné hypotézy.

Hypotéza je správně formulovaná tehdy, jestliže ji lze falzifikovat (Popperovo kritérium falzifikovatelnosti (Popper, 1997)). Podle Poppera nelze hypotézu empiricky dokázat, lze pouze usilovat o její falzifikaci na základě empirických dat; případně lze na základě nich zdi̊vodnit její přijatelnost.

Vědecké hypotézy se obvykle testují pomocí statistických metod (Anděl, 1978). Takovou hypotézu (tzv. alternativní hypotézu) formulovanou ve statistických termínech pak testujeme proti jinému tvrzení (tzv. nulové hypotéze), která vyjadřuje domněnku, že mezi zkoumanými proměnnými není žádný vztah. Nulovou hypotézu na určité hladině významnosti bud' zamítáme (a tedy přijímáme alternativní hypotézu), nebo ji nemůžeme zamítnout. Pokud zvolíme hladinu významnosti např. $5 \%$, znamená to, že existuje $5 \%$ pravděpodobnost toho, že nulovou hypotézu zamítáme a ona přesto platí (a nesprávně tedy přijímáme alternativní hypotézu).

V běžné školní výuce (na základní či střední škole) pracujeme obvykle s hypotézami, které nejsou ověřovány na základě statistických kritérií. Cílem výuky přírodních věd je naučit děti rozpoznat nebo formulovat myšlenku, která může být zkoumána a $\mathrm{v}$ rámci dané situace vhodnými postupy ověřena. Žák by měl umět posoudit, kdy je získaný důkaz validní, tj. kdy je možné z něj vyvodit relevantní závěr. Důležité také je, aby se děti naučily rozlišovat mezi otázkami, které věda může a které nemůže zodpovědět.

\section{Př́́KLAD AKTIVITY}

- Jirka s Petrem vzali puk a položili ho na koberec. Udeřili do něj hokejkou, puk se začal pohybovat a po určité době se zastavil. Jirka vyslovil hypotézu, že puk se zastavil, protože ho už nic netlačilo dopředu. Petr řekl, že puk se zastavil proto, že na něj působila třecí síla. Kterou hypotézu bys podpořil? Jakým pokusem bys vyslovené hypotézy potvrdil nebo vyvrátil? (př́klad aktivity podle Hejnové, 2004).

\section{3) EXPERIMENTOVÁNí}

Experimentem ${ }^{5}$ rozumíme takové jednání, jehož primárním účelem je vyvrátit (falzifikovat) hypotézu. V tomto smyslu můžeme experiment chápat jednak jako metodu poznání a jednak jako kritérium pravdivosti (platnost hypotézy však nemůže být experimentem dokázána absolutně, jak již bylo uvedeno výše). Vědecký pokus musí být proveden za předem stanovených podmínek, aby mohl být opakovatelný, a tím i ověřitelný (je-li to objektivně možné).

Experimentování zpravidla zahrnuje několik základních kroků. Nejprve je nutné stanovit výzkumný problém (např. na základě pozorování nebo záměrně realizovaného observačního experimentu, případně také na základě zkušenosti, studia literatury apod.), který lze empiricky ověrit (napřr. nás může zajímat problém „Jak

\footnotetext{
${ }^{5} \mathrm{~S}$ ohledem na paradigma př́rodních věd vycházíme v tomto článku z metodologie kvantitativního výzkumu, tj. máme zde na mysli zejména kvantitativní experimenty, které slouží ke zkoumání nějaké specifické zákonitosti (např. experimenty k určení kvantitativních závislostí), nebo experimenty, které slouží ke zkoumání souvislostí mezi proměnnými veličinami.
} 
závisi elektrický odpor kovového vodiče na teplotě?" ). Vlastní formulace problému (výzkumné otázky) pak předpokládá stanovení vhodných proměnných, mezi nimiž hledáme vztahy (elektrický odpor kovového vodiče, teplota), a způsob jejich měřní. V dalším kroku formulujeme hypotézu ve formě tvrzení, které vyjadřuje vztah mezi dvěma proměnnými („Elektrický odpor kovového vodiče roste se zvyšujici se teplotou. "). Na základě předpokladu platnosti hypotézy pak můžeme vyslovit předpovědi výsledku experimentu pro konkrétní př́ípady, které budeme v rámci experimentu zkoumat. Při tom je třeba ještě uvážit nezbytné předpoklady, abychom získali spolehlivé výsledky (viz bod 10 „Kontrola proměnných“). Např. můžeme vyslovit předpověd”: „Za předpokladu, že se nebude měnit délka vodiče, bude elektrický odpor měděného vodiče s rostouci teplotou rüst. "Poté ověřujeme (testujeme) předpověd” pomocí (testovacího) experimentu. Nakonec výsledky vyhodnotíme, tj. konstatujeme, že hypotéza byla vyvrácena, nebo na základě provedených experimentů můžeme zdůvodnit její přijatelnost a považovat ji tak za prozatímně ověřenou (hypotéza bude vyvrácena, pokud najdeme takový prrípad kovového vodiče, pro nějž by výše uvedené tvrzení neplatilo).

Ve výuce přírodních věd je experimentování základem badatelsky orientované výuky, o které jsme se zmínili již v první kapitole. Samostatné experimentování představuje nejvyšší úroveň IBSE. Předpokládá nejen dobrou úroveň osvojení základních př́rodovědných pojmů a vztahů mezi nimi, ale i osvojení všech potřebných dovedností. V tomto př́ipadě se jedná o tzv. otevřené bádání (open inquiry), při němž sami žáci sestavují výzkumné otázky, určují zpưsob a postup bádání a vyvozují z něho závěry. Pro realizaci v běžné škole bývá schůdnější tzv. řízené (nasměrované) bádání (guided inquiry), kdy je žákům zadán problém, který mají zkoumat (Hejnová, Kolářová \& Hotová, 2015). Sami pak navrhují postup, jak budou daný problém řešit. Učitel je $\mathrm{v}$ tomto případě průvodcem žáka při bádání, který zadává úkoly, poskytne pomůcky a př́padně doporučí vhodnou literaturu. Do práce žáků však zasahuje co nejméně. Jeho úkolem je vést žáky správným směrem tak, aby sami dospěli $\mathrm{k}$ vyřešení problému.

\section{ZÁVĚR}

V naší přehledové studii jsme chtěli ukázat, jakými zpo̊soby je možné rozvíjet vědecké myšlení žáků. Vycházeli jsme při tom zejména ze zahraničních zdrojů a výzkumů, které ukazují, že žáci si mohou osvojovat základní vědecké zásady prostřednictvím aktivit zaměřených na rozvoj vědeckého myšlení (viz např. již dříve uvedený projekt CASE (Adey, 1999); dále např. Shayer \& Adey, 1993; Han, 2013).

V českých školách se v oblasti přírodovědného vzdělávání žáci učí základům vědeckého myšlení zejména $\mathrm{v}$ rámci badatelsky orientované výuky. Zůstává ovšem otázkou, nakolik ji učitelé v rámci školní výuky opravdu realizují a do jaké míry

se při tom systematicky zaměřují na osvojování zásad vědeckého myšlení. Nicméně lze konstatovat, že i v českém vzdělávacím prostředí existují iniciativy jednotlivých učitelů a pedagogických odborníků (např. Bělecký, 2010; Dvořáková, 2011) i různých sdružení - např. metodické materiály sdružení Tereza (Kol., 2013), které předkládají v praxi vyzkoušené metody, jimiž je možné rozvíjet a hodnotit dovednosti vědeckého myšlení.

Myslíme si, že kromě osvojování konkrétních obsahů jednotlivých předmětů by stejná péče měla být věnována i osvojování obecnějších dovedností, např. dovedností zaměřených na rozvoj vědeckého myšlení. Proto by měly být vhodné akti- 
vity zařazovány ve větší míře do českých učebnic přírodních věd, podobně jako je tomu v některých zahraničních učebnicích (např. Armstrong et al., 2008). Za klíčové také považujeme, aby učitelé byli s touto problematikou systematičtěji seznamováni (např. již v rámci pregraduálního vzdělávání) a aby jim byla také poskytnuta dostatečná podpora např. ve formě seminářů, metodických materiálů, příkladů dobré praxe apod.

Ve výuce přírodovědných předmětů na základních a středních školách mají učitelé dobrou př́ležitost seznamovat žáky s postupy vědecké práce, přičemž mohou stavět zejména na přímé zkušenosti, které děti získávají v rámci různých aktivit. Jestliže žákům pomáháme osvojovat si vědecké myšlení, učíme je zároveň i kriticky myslet. Přirozeně tak u nich rozvíjíme klíčové dovednosti, které uplatní nejen v jiných oblastech vzdělávání, ale především v budoucnosti, ve svém dospělém životě.

\section{LITERATURA}

Adey, P. (1999). The Science of Thinking, and Science for Thinking: A Description of Cognitive Acceleration through Science Education (CASE). Innodata Monographs 2.

Ženeva: International Bureau of Education. Dostupné z http://www.ibe.unesco.org/fileadmin/user_upload/archive/Publications/ innodata/inno02.pdf

Anděl, J. (1978). Matematická statistika. Praha: SNTL.

Armstrong, T. et al. (2008). Discovering Science 7. Toronto: McGraw-Hill Ryerson.

Bělecký, Z. (2010). Vzdělávací strategie \%. Dostupné

z http://www.ucitelske-listy.cz/2010/01/zdenek-belecky-serial-vzdelavaci_09.html

Berg, E. (2013). The PCK of Laboratory Teaching: Turning Manipulation of Equipment into Manipulation of Ideas. Sciencia in educatione, 4(2), 74-92.

ČŠI - Česká školní inspekce. Hlavní zjištění PISA 2012. Dostupné z http://www.csicr.cz/cz/O-nas/Mezinarodni-setreni/PISA/Hlavni-zjisteni-PISA-2012/

Dvořák, L. et al. (2008). Lze učit fyziku zajímavěji a lépe? Praha: Matfyzpress.

Dvořák, L., Kekule, M. \& Žák, V. (2012). Výzkum v oblasti fyzikálního vzdělávání - co, proč a jak. Čskoslovenský časopis pro fyziku, 62(56), 325-330.

Dvořáková, I. (2011). Vědecké myšlení žáků - jak ho lze rozvíjet a testovat. In M. Randa (Ed.), Moderní trendy v př́pravě učitelů 5. Plzeň: Západočeská univerzita v Plzni.

[CD-ROM]. Dostupné

z http://kdf.mff.cuni.cz/lide/dvorakova/Plzen_prispevek_Dvorakova.pdf

Fajkus, B. (2005). Filosofie a metodologie vědy. Praha: Academia.

Fenclová, J. et al. (1984a). K perspektivám fyzikálního vzdělávání v didaktickém systému př́rodních věd. Praha: Academia.

Fenclová, J. (1984b). Didaktické myšlení a jednání učitele fyziky: cvičení z didaktiky fyziky. Praha: SPN.

Gagné, R. M. (1975). Podmínky učení. Praha: SPN.

Han, J. (2013). Scientific Reasoning: Research, Development, and Assessment [Disertační práce]. Ohio: The Ohio State University. 
Hejnová, E. (2004). Evaluace výsledkư fyzikálního vzdělávání na základních školách [Disertační práce]. Praha: MFF UK.

Hejnová, E. et al. (2009). Měřni fyzikálních veličin (CD). Praha: Prometheus.

Hejnová, E. et al. (2011). Vlastnosti látek a těles (CD). Praha: Prometheus.

Hejnová, E., Kolářová, K. \& Hotová, I. (2015). Inspirace pro badatelsky orientovanou výuku. In R. Seifert (Ed.), Jak získat žáky pro fyziku 2? Praha: JČMF. [CD-ROM]

Janoušková, S., Hubáčková, L., Pumpr, V. \& Maršák, J. (2014). Př́rodovědná gramotnost v preprimárním a raném období primárního vzdělávání jako prostředek zvýšení zájmu o studium přírodovědných a technických oborů. Sciencia in educatione, $5(1), 36-49$.

Jinks, J. (1997). The Science Processes. Dostupné

z http://my.ilstu.edu/ jdpeter/THE\%20SCIENCE\%20PROCESSES.htm

Kekule, M. \& Žák, V. (2010). Postoje žáků k výuce fyziky v České republice - vybrané výsledky. Sciencia in educatione, 1(1), 51-71.

Koenig, J. A. (Ed.). (2011). Assessing 21st century skills. Washington: National Academies Press. Dostupné z http://www.nap.edu/catalog.php?record_id=13215

Kol. (2013). Průvodce pro učitele badatelsky orientovaným vyučováním. Praha: Sdružení Tereza. Dostupné z http://www.zsmltu.cz/dum/BOV/BOV/DATA/ 01_PRUVODCE_PRO_UCITELE/00_PR\%D9VODCE_CELA_KNIHA/ 01_Pruvodce_pro_ucitele.pdf

Koukolík, F. (2013). O mozku, vědomí a sebeuvědomování. Praha: Karolinum.

Kratochvíl, M. (2006). Jean Piaget - filosof a psycholog (uvedení do genetické epistemologie). Opava: Triton.

Krykorková, H. \& Chvál, M. (2001). Rozvoj metakognice - cesta k hodnotnějšímu poznání. Pedagogika, 51(2), 185-196.

Krykorková, H. (2008). Kognitivní svébytnost, teoretická východiska a okolnost jejího rozvíjení. Pedagogika, 58(2), 140-155.

Kuhn, T. S. (1997). Struktura vědeckých revolucí. Praha: Oikúmené.

Minárechová, M. (2014). História induktívného prístupu v prírodovednom vzdelávaní v USA a jeho súčasná reflexia na Slovensku. Scientia in educatione, 5(1), 2-19.

Ogborn, J. (2012). Curriculum Development in Physics: Not Quite So Fast! Scientia in educatione, 3(2), 3-15.

Padilla, J. (1990). The Science Process Skills. Dostupné

z https://www.narst.org/publications/research/skill.cfm

Papáček, M. (2010a). Badatelsky orientované přírodovědné vyučování - cesta pro biologické vzdělávání generací Y, Z a alfa? Scientia in educatione, 1(1), 33-49.

Papáček, M. (2010b). Limity a šance zavádění badatelsky orientovaného vyučování př́rodopisu a biologie v České republice. In M. Papáček (Ed.), Didaktika biologie v Čské republice 2010 a badatelsky orientované učení. DiBi 2010 (145-162). Ceské Budějovice: Jihočeská univerzita.

Piaget, J. (1999). Psychologie inteligence. Praha: Portál.

PISA (1999). Měření vědomostí a dovedností - Nová koncepce hodnocení žákư. Praha: ÚIV. Dostupné z http://www.csicr.cz/getattachment/cz/O-nas/Mezinarodni-setreniarchiv/PISA/PISA-2000/Mereni-vedomosti-a-dovednosti-publikace.pdf 
Popper, K.R. (1997). Logika vědeckého výzkumu. Praha: Oikúmené.

Průcha, J., Walterová, E. \& Mareš, J. (2009). Pedagogický slovník. Praha: Portál.

Richterek, L. (2008). Filozofické problémy př́rodních věd. Olomouc: UPOL. Dostupné z http://esfmoduly.upol.cz/publikace/fppv.pdf

Rojko, M. (1995). Fyzika kolem nás. Fyzika I pro základní a občanskou školu. Praha: Scientia.

Shayer, M. \& Adey, P.S. (1993). Accelerating the development of formal thinking in middle and high school students IV: three years after a two-year intervention. Journal of Research in Science Teaching, 30(4), 351-366.

Straková, J. (2010). Pedagogické činnosti českých učitelů v mezinárodním srovnání. Pedagogika, 60(3-4), 81-96.

Stuchlíková, I. \& Mareš, J. (2014). Rozvoj metakognitivních kompetencí žáků - otevřený úkol. Pedagogika, 64(3), 267-269.

Trna, J. (1998). Diagnostika dovedností žáků ve výuce fyziky [Habilitační práce]. Brno: PF MU.

Eva HeJnovÁ, eva.hejnova@ujep.cz

Univerzita J. E. Purkyně v Ústí nad Labem, Př́rodovědecká fakulta

Katedra fyziky

České mládeže 8, 40096 Ústí nad Labem, Česká republika

DALIBOR HeJnA, dalibor.hejna@tul.cz

Technická univerzita v Liberci, Fakulta přírodovědně-humanitní a pedagogická

Katedra filozofie

Univerzitní náměstí 1410/1, 46117 Liberec, Česká republika 